\title{
Khurtov M.S., Vakhitova G.V. On the ratio of second and preemptive rights to purchase shares in a limited liability company
}

FSBEI HE Bashkir State University (Russia, Ufa)

doi: $10.18411 / \mathrm{j}-10-2019-36$

idsp: ljournal-10-2019-36

Abstract

This article examines the legal nature of such categories as preemptive and second rights, and their relationship to each other.

Keywords: preemptive right to purchase a share in a limited liability company, preemptive rights, property rights, second rights.

The civilist doctrine has developed a category of so-called second rights, which are a prerequisite for the acquisition of other rights and obligations [11]. By examining the structure and content of preemptive law, one can find similarities with second law and, accordingly, ask the question of the ratio of second and preemptive law, whether the latter are absorbed by the first. A distinctive feature of second rights is that someone's duty does not correspond with them, second rights do not oblige anyone, but only connect in a certain way [12]. Preemptive rights in themselves are of great interest, since the provision of preemptive rights legislatively limits the principle of freedom of contract [3].

The first who proposed and developed the concept of second rights, having formed their essential features and characteristics, was the German civilist Emil Zekkel. Defining second rights as a subjective private law, the content of which is the ability to establish a specific legal relationship through a unilateral transaction [6]. An example of second law is the acceptance of an offer. In Germany, the concept of second-hand rights was adopted, which cannot be said about Russian civil law. Agarkov M.M. in his work denied understanding of second law as a private law, described second law as a form of legal capacity, dividing legal capacity itself into static (the abstract ability of everyone to have any rights and duties based on the law) and dynamic (the ability to have certain specific rights and obligations depending on relationship of a person with other persons) relating second rights to the latter [1]. The concept developed and proposed by M. M. Agarkov was revolutionary, but could not find its supporters. The proposed concept was criticized by Bratus S.N. adhering to the position of recognition of the existence of second rights [4]. Alekseev S.S. proposed to consider second rights as special powers on which a unilaterally binding transaction is based [2]. There is also an approach developed by Pevzner A.G. which recognizes the second rights as powers included in the subjective right along with the right to carry out their own actions, both actual and legally significant, the right to demand the fulfillment of obligations from another subject, as well as the right to defense, while dividing the second power into two groups. He related to the first group the right of the person who received the offer to accept it, the right of the heir to accept the inheritance, and to the second group the right arising from the existing legal relationship, for example, the right to choose by the debtor what action to fulfill the obligation (alternative obligation). Differentiation of second rights is based on the fact that in the first case, second law allows establishing legal relations by unilateral expression of will, and in the second case it is aimed at changing or terminating the legal relationship [9]. The existence of second rights is recognized by such scientists as Karapetov A.G., Bevzenko R.S., Vasnev V.V., Babaev A.B. while the last author, conducting a study of second-hand rights, significantly made a bias in determining their legal nature and proposed to characterize them as subjective civil law, the difference of which is the absence of a corresponding duty. Karapetov A.G. commenting on Art. 435 of the Civil Code of the Russian Federation indicates the fact that upon delivery of an offer to the addressee, the addressee has a second 
(transformative) right to unilaterally express an agreement to enter into force, and in the meantime the offeror is undergoing uncertainty[7].

Considering the various concepts of legal nature and the concepts of second rights existing in the doctrine, we can establish that there is no consensus on this category. The main problem is the very recognition of the existence of second rights and the definition of their concept.

Among researchers of second rights, there is a position about the inadmissibility of assigning priority rights to second. Arguing his position with the fact that "the exercise of preemptive rights cannot be accomplished solely by the will of an authorized person, that is, through a unilateral transaction" [8].

Other authors, on the contrary, believe that preemptive rights can be attributed to the category of second rights [10]. Substantiating the possibility of assigning preemptive rights to second ones, the authors assert the identity of such concepts as an offer and notification by the owner of shared ownership of his intention to transfer the share to the holder of the preemptive right. The authors argue that for the addressee of the offer and for the addressee of the notice having the preemptive right, the consequences are the same, they have the second right to unilaterally establish legal relations, and the sender is undergoing uncertainty at this point.

Glushkova E. A. adheres to another point of view. Arguing the difference between second law and preemptive law on the basis of the analysis of Art. 435 and 436 of the Civil Code of the Russian Federation. In accordance with the Civil Code, the following signs of an offer can be identified: targeting, which implies the presence of one or more specific recipients; the certainty of the offer, which should include the essential conditions, as well as other conditions sufficient to complete the transaction; it must express the intention of the person to conclude a contract. As for the analysis of the notice sent to the holder of the preemptive right, it is also possible to identify such signs as targeting and certainty. The first sign also manifests itself in the fact that the notice should be addressed to one or more specific individuals, and the second that the content should be specific and include all essential conditions.

The principal difference is the offer and the notice, firstly, the notice does not contain the intention of the person to conclude the contract, but by virtue of clause 2 of Article 250 of the Civil Code of the Russian Federation, the seller is obliged to notify the owners of the preemptive right, thus it can be argued that the person who intends to transfer the share in the common property to a third party has no intention to enter into a contract with the addressee in the notice, and the notice itself is the sender's obligation.

Accordingly, the offer and notice by their nature are not completely identical designs [13]. The difference is expressed in the target nature of these institutions, in the first it is a clearly defined intention of a person to conclude a contract, and in the second it is a person's obligation to notify other persons of preemptive rights. Also, at the offer, the identity of the addressee matters, and upon notification, the person can, as in the case of his refusal with any third party, conclude an agreement on the alienation of the share with the addressee.

The distinction between the two institutions is important for determining the status of the addressee of the offer and the holder of the preemptive right who is the recipient of the notice. In the first case, the addressee receives the right to accept the offer, that is, he has the unilateral right to establish legal relations at his discretion. In the second case, the person does not have the right to unilateral actions to establish legal relations, the recipient of the notice can only agree to alienate the share to third parties or send an offer to the person who intentionally alienate the share in the common property. A feature of second law is the absence of a counter obligation, and with a more detailed analysis of preemptive law within the meaning of Art. 250 of the Civil Code of the Russian Federation, it can be argued that there is a corresponding liability[5]. 
Preemptive rights also apply to corporate relations. Based on the fact that preemptive rights are diverse in nature, the preemptive right in a corporate relationship is offset by an obligation, and the notice is initially in accordance with clause 5 c. 21 of the Law on LLCs has been replaced by an offer, which implies that the holder of the pre-emptive right can accept the offer by unilateral expression of will, and the person alienating the share of the LLC is undergoing uncertainty. Therefore, the scientific theory of the distinction between second law and preemptive law, based on the differences of such constructions as the offer and the notice, is unreasonable [14].

According to Karnushin V.E. the preemptive right to purchase an LLC share is a second right that exists within the framework of a contractual relationship, since the purchase of an LLC share is always invested in the contract, but it is not the content of such a legal relationship, and the second nature is expressed in the possibility of a unilateral change in the legal relationship. In addition, the author focuses on the fact that Art. 21 of the Law on LLC contains two seconds rights: the first is the right to purchase a share of LLC by participants of the organization; the second is the right to purchase a share of the LLC by the organization itself. Noting the fact that these rights exist within a limited time frame established by law for acceptance of an offer, the second right is also dependent on the legal actions of other participants in the organization.

Based on the foregoing, it can be argued that despite the multiplicity of points of view on the problem, their very presence is an important indicator confirming attention to it. The preemptive right to purchase an LLC share is by its nature a second right, as evidenced by the fact that the seller of the share is opposed to being bound by his preemptive right with other participants.

$$
* * *
$$

1. Agarkov M.M. Obligation under Soviet civil law. All-Union Institute of Legal Sciences of the NKJ USSR: scientific works. Vol. 3. M.: Legal Publishing House of the NKJ USSR, 1940. S. 72.

2. Alekseev S.S. Unilateral transactions in the mechanism of civil law regulation // Anthology of the Ural civil law. 1925-1989. Collection of articles M .: Statute, 2001.S. 64.

3. Bashirina E.N., Firsova N.V. Restriction of the principle of freedom of contract in accession agreements in the light of changes in civil legislation // Eurasian Law Journal 2016. No. 4 (95). S. 129-130.

4. Bratus S.N. Subjects of civil law. M .: State Publishing House of Legal Literature, 1950.P. 367.

5. Glushkova E.A. To the question of the legal nature of preemptive civil rights as subjective rights // Actual problems of Russian law, No. 7. M .: Statut, 2015. P. 83. [Electronic resource]. URL http://aprpmsal.ru/arhive/arhive_1162.html?year=2015 (accessed: 04/22/2019)

6. Zekkel E. Secondary rights in civil law // Bulletin of civil law. 2007.S. 1-3. Legal portal Center Coast [Electronic resource]. URL: http://center-bereg.ru/d1206.html

7. Karapetov A.G. Contract and law of obligations (general part): article-by-article commentary to Art. 307-453 of the Civil Code of the Russian Federation. M .: M-Logos, 2017.S. 1020.

8. Onina A.A. Preemptive right to purchase in the civil law of the Russian Federation Ufa, 2009. 32, 56-57 p. // Digital library of dissertations [Electronic resource]. URL: https://www.dissercat.com/catalog/ pedagogicheskie-nauki (accessed: 04/22/2019).

9. Pevzner A.G. The concept and types of subjective civil rights. M .: 1961.S. 116.

10. Sklovsky K., Smirnova M. Institute of preemptive purchase in Russian and foreign law // Economy and Law. 2003.S. 103 .

11. Firsova N.V. Problems of the legal nature of the preemptive right to purchase // Bulletin of the Moscow University of the Ministry of Internal Affairs of Russia. Publisher: Moscow University of the Ministry of Internal Affairs of the Russian Federation. V.Ya. Kikotya (Moscow). 2009. No. 12. P. 128-131.

12. Firsova N.V. General shared ownership as an institution of civil law abstract of thesis diss. Cand. legal sciences. M., 2010. 26s

13. Firsova N.V. Common shared ownership as an institution of civil law: Dis. Cand. legal sciences. M., 2010.190s.

14. Firsova N.V. The legal nature of the share in total shared ownership: theory and practice // Bulletin of BIST / Bashkir Institute of Social Technologies. 2009. No3. S. 40-41. 